\title{
Annual Report on the External Quality Assessment of Diagnostic Genetics in Korea (2013)
}

Mi-Ae Jang ${ }^{1}$, Sang-Yong Shin ${ }^{1}$, Seungman Park ${ }^{2,3}$, Moon-Woo Seong' ${ }^{2}$, Sung Sup Park ${ }^{2}$, and SunHee Kim ${ }^{1}$, as Diagnostic Genetics Subcommittee, The Korean Association of Quality Assurance for Clinical Laboratory

${ }^{1}$ Department of Laboratory Medicine and Genetics, Samsung Medical Center, Sungkyunkwan University School of Medicine; ${ }^{2}$ Department of Laboratory Medicine, Seoul National University Hospital, Seoul National University College of Medicine; ${ }^{3}$ Green Cross Laboratories

\section{Corresponding author:} Sun-Hee Kim

Department of Laboratory Medicine and Genetics, Samsung Medical Center, Sungkyunkwan University School of Medicine, 81 Irwon-ro, Gangnam-gu, Seoul 135-710, Korea

Tel: +82-2-3410-2704

Fax: +82-2-3410-2719

E-mail: sunnyhk@skku.edu

pISSN: 1225-097X

eISSN: 2288-7261
Quality control for genetic tests has become more important as the test volume and clinical demands increase dramatically. The diagnostic genetics subcommittee of the Korean Association of Quality Assurance for Clinical Laboratories performed two trials for cytogenetics and molecular genetics surveys in 2013. A total of 43 laboratories participated in the cytogenetic surveys, 30 laboratories participated in the fluorescent in situ hybridization surveys, and 122 laboratories participated in the molecular genetics surveys in 2013 . Almost all of them showed acceptable results. However, some laboratories had unacceptable results for karyotype nomenclature, detection of complex cytogenetic abnormalities in hematologic neoplasms and constitutional anomalies. The molecular genetics surveys included various tests: Mycobacterium tuberculosis detection, hepatitis B and C virus detection and quantification, human papilloma virus genotyping, gene rearrangement tests for leukaemia and lymphomas, genetic tests for $J A K 2$, fms-related tyrosine kinase 3, Nucleophosmin, cancer-associated genes (KRAS, EGFR and BRAF), hereditary breast and ovarian cancer genes (BRCA1 and BRCA2), Li-Fraumeni syndrome (TP53), Wilson disease $(A T P 7 B)$, achondroplasia (FGFR3), Huntington disease, spinocerebellar ataxia, spinal and bulbar muscular atrophy, mitochondrial encephalopathy with lactic acidosis and stroke like episodes, myoclonic epilepsy associated with ragged-red fibers, Prader-Willi/ Angelman syndrome, Duchenne muscular dystrophy, spinal muscular atrophy, Fragile X syndrome, non-syndromic hearing loss and deafness (GJB2), apolipoprotein E genotyping, methylenetetrahydrofolate reductase genotyping, $\mathrm{ABO}$ genotyping and DNA sequence analysis. Molecular genetic surveys showed excellent results for most of the participants. The external quality assessment program for genetic analysis in 2013 was proved to be helpful for continuous education and evaluation of quality improvement.

(J Lab Med Qual Assur 2014;36:71-83)

Key Words : Quality assurance, Genetics, Cytogenetics

\section{서론}

대한임상검사정도관리협회 진단유전학분과위원회는 2013 년에도 예년과 마찬가지로 세포유전검사와 분자유전검사에 대한 각 2 회의 신빙도조사를 실시하였다. 염색체검사의 경우 2005년 신빙도조사부터 합격/불합격의 기준을 마련하여 이에 따라서 판정하였으며, 발송된 10예의 정도관리물질 중 6예 이 상, 즉 $60 \%$ 이상의 검사결과에서 acceptable performance를 보인 경우를 최종 합격으로 판정하고 있다[1-4]. 2009년부터 형광제자리부합법(fluorescent in situ hybridization, FISH) 검사를 신빙도조사에 포함하여 실시하였으며[3], 2013년부터 처음으로 염색체검사와 마찬가지로 2회의 FISH검사를 실시 하였다.

분자유전검사는 2012년도에 시행했던 백혈병/림프종 분자 유전검사, JAK2 분자유전검사, $A P O E$ 유전자형 분자유전 검사, fragile $\mathrm{X}$ syndrome 분자유전검사, human papilloma virus (HPV), Mycobacterium tuberculosis, hepatitis B ( $\mathrm{HBV})$, hepatitis C $(\mathrm{HCV})$ 분자진단검사 등의 29종 검사항 
목에 Nucleophosmin (NPM1), fms-related tyrosine kinase 3 (FLT3) 분자유전검사를 추가로 포함하여 시행하였다. 2013 년 2차 신빙도조사부터 FLT3 분자유전검사의 경우 FLT3ITD, FLT3-TKD로 구분하여 시행하였으며, DNA 염기서열 분석항목에는 새로운 유전자와 다양한 종류의 돌연변이를 포 함하도록 구성하였다. 저자들은 2013년 실시되었던 진단유전 학검사의 신빙도조사결과를 분석하여 보고하고자 한다.

\section{재료 및 방법}

\section{1. 세포유전검사}

2013년도에는 2회에 걸쳐 각각 5예와 4예의 정도관리용 사 진 그리고 1 예의 말초혈액 검체를 발송하여 염색체검사의 핵 형분석에 대한 신빙도조사를 실시하였다. 2013년 4월에 실시 된 1차 염색체검사 신빙도조사 프로그램에서는 총 5예(13CY$01,13 \mathrm{CY}-02,13 \mathrm{CY}-03,13 \mathrm{CY}-04,13 \mathrm{CY}-05)$ 에 대하여 환 자의 간단한 임상정보를 발송하고 대한임상검사정도관리협 회 홈페이지(http://www.lab-qa.org) 또는 한국유전자검사 평가원 홈페이지(http://www.kigte.org)에서 세포분열중기 사진을 다운로드받아 분석하도록 하였다. 2013년 9월에 실 시된 2차 염색체검사 신빙도조사 프로그램은 총 4예(13CY06 13CY-07, 13CY-08, 13CY-09)에 대하여 마찬가지로 임 상정보를 발송하였으며 1예(13CY-10)에 대해서는 말초혈 액 검체를 발송하였다. 검사결과의 보고는 각 검사실에서 사 용하는 통상적 방법으로 분열중기세포를 분석한 후 최종 핵 형결과를 인체 염색체 명명법의 국제규약 즉, International System of Human Cytogenetic Nomenclature (ISCN) 2009 또는 2013의 단축형에 따라 기술하도록 하였다[5]. 결과분석 방법으로는 각 검체에 대한 핵형을 $\mathrm{M}$ : modal chromosome number, S: sex chromosome designation, A: recognition of abnormalities, $\mathrm{N}$ : karyotype nomenclature와 같은 $\mathrm{M}$, $\mathrm{S}, \mathrm{A}, \mathrm{N}$ 의 네 가지 요소로서 평가하였다. 각 네 가지 요소 에 대한 평가등급은 $\square, 1,2,3$, 으로 분류하였으며, 각 각 $\square$ : not graded, 11: good performance, 2]: acceptable performance, 3: unacceptable performance를 나타낸다. 2001년도부터는 지난 5년간 성적을 바탕으로 4곳의 참고기관 을 선정하여 이들의 결과를 참고하였고, 각 검체에 대한 핵형 의 target value는 '참고기관의 $75 \%$ 이상 및 참여기관 다수의 의견 일치가 있는 경우’로 정의하였다. 적절한 절단점으로 인 정하는 기준은 'two-band rule'를 따랐는데 이는 최빈수의 절 단점으로부터 two-band 또는 two-subband 내에 있는 절단 점만을 인정하는 것이다. 각 기관에서 회신한 핵형의 명명이
ISCN 2009 또는 2013의 원칙에 벗어난 경우, 결과요약지의 의견란에 구체적으로 평가의견을 기술하였다.

$\mathrm{FISH}$ 검사에 대한 신빙도조사사업은 2회에 걸쳐 각각 3예 와 4예의 FISH검사용 슬라이드를 발송하였다. 2013년 4월 에 실시된 1차 FISH검사항목은 총 3예(13CYF-01, 13CYF$02,13 \mathrm{CYF}-03)$ 로 trisomy 21, BCR/ABL, EGR1항목에 대 해서 실시하였다. 2013년 9월에 실시된 2차 FISH검사항목 은 총 4예(13CYF-06, 13CYF-07, 13CYF-08, 13CYF-09) 로 trisomy 21, DiGeorge syndrome on 22q11.2, CBFB, $A M L 1 / E T O$ 항목에 대해서 실시하였다. 발송된 FISH 슬라이 드는 각 항목별로 이상이 관찰된 검체로 슬라이드를 제작한 것으로, 참가기관별로 신빙도조사사업에 참여하는 항목에 대 해서 슬라이드를 2장씩 보냈다. 각 참가기관에서는 받은 슬라 이드에 각 검사실에서 사용하는 통상적 방법으로 검사를 시 행한 후 ISCN 2009 또는 2013에 따른 명명법과 함께 signal pattern에 대한 판독결과를 보고하도록 하였다[5]. 합격, 불합 격 여부는 signal pattern에 대한 판독결과만을 기준으로 판단 하였다.

\section{2. 분자유전검사}

2013년도 분자유전검사 신빙도조사는 2회에 걸쳐 시행되었 으며 1차는 31 종목, 2 차는 32 종목에 대하여 검체를 발송하였 다. 정도관리물질 제조와 준비는 Table 1 과 같이 시행하였다. 각 기관의 보고에 따라 검사방법, 검사결과 및 검사방법별 검 사결과를 비교분석하였으며, 기관별 보고결과에 대하여 기본 적인 평가(acceptable, unacceptable)를 실시하였다.

\section{결과}

\section{1. 세포유전검사}

2013년 실시된 1, 2차 염색체검사 신빙도조사에서는 총 43 개 기관에 발송하여 43 개 기관으로부터 결과회신을 받았다. 검체별 결과분석 내용은 Table 2 와 같다. 제 1,2 차 염색체검 사 신빙도조사결과를 제시된 합격/불합격의 기준에 따라 판 정하였을 때 참여한 기관 중 총 42 기관이 합격 판정을 받았다. 2013년 4월에 실시된 제1차 FISH검사 신빙도조사사업에는 총 30 개 기관에 발송하여 30 개 기관으로부터 결과회신을 받았 다. 9월에 실시된 제 2 차 FISH 신빙도조사에서는 1 개 기관에 서 상반기 1 회만 참여하여, 총 30 개 기관에 발송하여 29 개 기 관으로부터 결과회신을 받았다. FISH검사항목별 사용하는 제 조사와 probe type 및 분석결과는 Table 3 과 같다. 
Mi-Ae Jang et al • EQA Report of Diagnostic Genetics (2013)

Table 1. Survey tests and specimens for external quality assessment of molecular genetic test survey in 2013

\begin{tabular}{|c|c|c|c|c|}
\hline Tests & Specimens & Test specimens of 1 st trial & Specimens & Test specimens of 2 nd trial \\
\hline \multirow[t]{2}{*}{$\mathrm{HPV}$} & MD1301-A & HPV positive cell line & MD1302-A & HPV positive cell line \\
\hline & MD1301-B & Human normal control cell line & MD1302-B & Human normal control cell line \\
\hline \multirow[t]{2}{*}{ M. tuberculosis } & MD1301-C & M. tuberculosis & MD1302-C & M. tuberculosis \\
\hline & MD1301-D & NTM & MD1302-D & NTM \\
\hline \multirow[t]{3}{*}{ HBV } & MD1301-E & HBV high positive plasma & MD1302-E & HBV low positive plasma \\
\hline & MD1301-F & HBV low positive plasma & MD1302-F & Normal pooled plasma \\
\hline & MD1301-G & Normal pooled plasma & MD1302-G & HBV high positive plasma \\
\hline \multirow[t]{3}{*}{$\mathrm{HCV}$} & MD1301-H & HCV high positive plasma & MD1302-H & HCV high positive plasma \\
\hline & MD1301-I & HCV low positive plasma & MD1302-I & HCV low positive plasma \\
\hline & MD1301-J & Normal pooled plasma & MD1302-J & Normal pooled plasma \\
\hline \multirow[t]{2}{*}{ Leukemia/lymphoma } & MD1301-01 & Leukemia cell line ( $B C R / A B L$ positive) & MD1302-01 & Leukemia cell line ( $B C R / A B L 1$ positive) \\
\hline & MD1301-02 & Leukemia cell line (TEL/AML1 positive) & MD1302-02 & Leukemia cell line (AML1/ETO positive) \\
\hline \multirow[t]{2}{*}{$J A K 2$} & MD1301-05 & Cell line with $J A K 2$ mutation & MD1302-03 & Cell line with $J A K 2$ mutation \\
\hline & MD1301-06 & Normal cell line & MD1302-04 & Normal cell line \\
\hline \multirow[t]{2}{*}{ FLT3 -ITD } & MD1301-07 & Extracted DNA with FLT3-ITD mutation & MD1302-05 & Extracted DNA with FLT3-ITD mutation \\
\hline & MD1301-08 & Normal DNA & MD1302-06 & Normal DNA \\
\hline \multirow[t]{2}{*}{ FLT3-TKD* } & - & - & MD1302-07 & Normal DNA \\
\hline & - & - & MD1302-08 & Extracted DNA with FLT3-TKD mutation \\
\hline \multirow[t]{2}{*}{ NPM1 } & MD1301-09 & Extracted DNA with NPM1 mutation & MD1302-09 & Extracted DNA with NPM1 mutation \\
\hline & MD1301-10 & Normal DNA & MD1302-10 & Normal DNA \\
\hline \multirow[t]{2}{*}{ KRAS } & MD1301-11 & Cell line with $K R A S$ mutation & MD1302-11 & Cell line with KRAS mutation \\
\hline & MD1301-12 & Normal cell line & MD1302-12 & Normal cell line \\
\hline \multirow[t]{2}{*}{$B R A F$} & MD1301-13 & Cell line with $B R A F$ mutation & MD1302-13 & Cell line with $B R A F$ mutation \\
\hline & MD1301-14 & Normal cell line & MD1302-14 & Normal cell line \\
\hline \multirow[t]{2}{*}{$E G R F$} & MD1301-15 & Cell line with EGFR mutation & MD1302-15 & Cell line with EGFR mutation \\
\hline & MD1301-16 & Normal cell line & MD1302-16 & Normal cell line \\
\hline \multirow[t]{2}{*}{ KIT } & MD1301-17 & Cell line with KIT mutation & MD1302-17 & Cell line with KIT mutation \\
\hline & MD1301-18 & Normal cell line & MD1302-18 & Normal cell line \\
\hline \multirow[t]{2}{*}{$B R C A 1$ and $B R C A 2$} & MD1301-19 & Cell line with $B R C A 2$ mutation & MD1302-19 & Extracted DNA with $B R C A 1$ mutation \\
\hline & MD1301-20 & Normal cell line & MD1302-20 & Normal cell line \\
\hline \multirow[t]{2}{*}{ TP53 } & MD1301-21 & Cell line with TP53 mutation & MD1302-21 & Normal cell line \\
\hline & MD1301-22 & Normal cell line & MD1302-22 & Cell line with TP53 mutation \\
\hline \multirow[t]{2}{*}{$A T P 7 B$} & MD1301-23 & Extracted DNA with $A T P 7 B$ mutation & MD1302-23 & Extracted DNA with $A T P 7 B$ mutation \\
\hline & MD1301-24 & Normal DNA & MD1302-24 & Normal DNA \\
\hline \multirow[t]{2}{*}{ Achondroplasia } & MD1301-25 & Normal DNA & MD1302-25 & Extracted DNA with FGFR3 mutation \\
\hline & MD1301-26 & Normal DNA & MD1302-26 & Normal DNA \\
\hline \multirow[t]{2}{*}{ GJB2 } & MD1301-27 & Normal cell line & MD1302-27 & Normal cell line \\
\hline & MD1301-28 & Normal cell line & MD1302-28 & Extracted DNA with GJB2 mutation \\
\hline \multirow[t]{2}{*}{ TGFBI } & MD1301-29 & Extracted DNA with TGFBI mutation & MD1302-29 & Extracted DNA with TGFBI mutation \\
\hline & MD1301-30 & Normal DNA & MD1302-30 & Normal DNA \\
\hline
\end{tabular}


Mi-Ae Jang et al • EQA Report of Diagnostic Genetics (2013)

Table 1. Continued

\begin{tabular}{|c|c|c|c|c|}
\hline Tests & Specimens & Test specimens of 1 st trial & Specimens & Test specimens of 2 nd trial \\
\hline \multirow[t]{2}{*}{ HD } & MD1301-31 & $\begin{array}{l}\text { Extracted DNA with HD mutation } \\
\text { (allele with full penetrance) }\end{array}$ & MD1302-31 & $\begin{array}{l}\text { Extracted DNA with HD mutation } \\
\text { (allele with full penetrance) }\end{array}$ \\
\hline & MD1301-32 & $\begin{array}{l}\text { Extracted DNA with HD mutation } \\
\text { (intermediate allele) }\end{array}$ & MD1302-32 & Normal DNA \\
\hline \multirow[t]{2}{*}{ SCA } & MD1301-33 & Extracted DNA with SCA mutation & MD1302-33 & Extracted DNA with SCA mutation \\
\hline & MD1301-34 & Normal DNA & MD1302-34 & Normal DNA \\
\hline \multirow[t]{2}{*}{ SBMA } & MD1301-35 & Extracted DNA with $A R$ mutation & MD1302-35 & Extracted DNA with $A R$ mutation \\
\hline & MD1301-36 & Normal DNA & MD1302-36 & Normal DNA \\
\hline \multirow[t]{2}{*}{ MELAS } & MD1301-37 & Extracted DNA with MELAS mutation & MD1302-37 & Extracted DNA with MELAS mutation \\
\hline & MD1301-38 & Normal DNA & MD1302-38 & Normal DNA \\
\hline \multirow[t]{2}{*}{ MERRF } & MD1301-39 & Extracted DNA with MERRF mutation & MD1302-39 & Normal DNA \\
\hline & MD1301-40 & Normal DNA & MD1302-40 & Extracted DNA with MERRF mutation \\
\hline \multirow[t]{2}{*}{ PW/AS } & MD1301-41 & Extracted DNA with PW mutation & MD1302-41 & Extracted DNA with PW mutation \\
\hline & MD1301-42 & Normal DNA & MD1302-42 & Extracted DNA with AS mutation \\
\hline \multirow[t]{2}{*}{ DMD } & MD1301-43 & $\begin{array}{l}\text { Extracted DNA with } D M D \text { mutation } \\
\text { (duplication) }\end{array}$ & MD1302-43 & $\begin{array}{l}\text { Extracted DNA with DMD mutation } \\
\text { (duplication) }\end{array}$ \\
\hline & MD1301-44 & Extracted DNA with DMD mutation (deletion) & MD1302-44 & Normal DNA \\
\hline \multirow[t]{2}{*}{ SMA } & MD1301-45 & Extracted DNA with SMN1 mutation & MD1302-45 & Normal DNA \\
\hline & MD1301-46 & $\begin{array}{l}\text { Extracted DNA with SMN1 mutation/ } \\
\text { Normal DNA }\end{array}$ & MD1302-46 & Extracted DNA with SMN1 mutation \\
\hline \multirow[t]{2}{*}{ APOE genotype } & MD1301-47 & Cell line with $A P O E \varepsilon 3 / \varepsilon 4$ genotype & MD1302-47 & Cell line with $A P O E \varepsilon 3 / \varepsilon 4$ genotype \\
\hline & MD1301-48 & Cell line with $A P O E \varepsilon 2 / \varepsilon 3$ genotype & MD1302-48 & Cell line with $A P O E \varepsilon 3 / \varepsilon 3$ genotype \\
\hline \multirow[t]{2}{*}{ MTHFR genotype } & MD1301-49 & Cell line with MTHFR 677C/T heterozygote & MD1302-49 & Cell line with MTHFR 677C/T heterozygote \\
\hline & MD1301-50 & Cell line with wild type & MD1302-50 & Cell line with MTHFR 677C/T heterozygote \\
\hline \multirow[t]{2}{*}{ ABO genotype } & MD1301-51 & Extracted DNA with cis-AB/O genotype & MD1302-51 & Extracted DNA with A/B genotype \\
\hline & MD1301-52 & Extracted DNA with A/B genotype & MD1302-52 & Extracted DNA with cis-AB/O genotype \\
\hline \multirow[t]{2}{*}{ FMR1 } & MD1301-53 & Cell line with FMR1 mutation & MD1302-53 & $\begin{array}{l}\text { Cell line with FMR1 mutation } \\
\text { (pre-mutation) }\end{array}$ \\
\hline & MD1301-54 & Normal cell line & MD1302-54 & $\begin{array}{l}\text { Cell line with FMR1 mutation } \\
\text { (full-mutation) }\end{array}$ \\
\hline \multirow[t]{4}{*}{ DNA sequencing } & SEC1301-01 & Sequences with NF1 mutation & SEC1302-01 & Sequences with $D M D$ mutation \\
\hline & SEC1301-02 & Sequences with TSC1 mutation & SEC1302-02 & Sequences with $V H L$ mutation \\
\hline & SEC1301-03 & Sequences with $K C N Q 1$ mutation & SEC1302-03 & Sequences with $A B C D 1$ mutation \\
\hline & SEC1301-04 & Sequences with $M L H 1$ mutation & SEC1302-03 & Sequences with $\mathrm{NOTCH} 3$ mutation \\
\hline
\end{tabular}

Abbreviations: M. tuberculosis, Mycobacterium tuberculosis; HPV, human papilloma virus; HBV, hepatitis B virus; HCV, hepatitis C virus; NTM, nontuberculous mycobacteria; HD, Huntington disease; SCA, spinocerebellar ataxia; SBMA, spinal and bulbar mulscular atrophy; MELAS, mitochondrial encephalomyopathy, lactic acidosis, and stroke-like episodes; MERRF, myoclonic epilepsy associated with ragged-red fibers; PW/AS, Prader-Willi/Angelman syndrome; DMD, Duchenne muscular dystrophy; SMA, spinal muscular atrophy; FLT3, fms-related tyrosine kinase 3; ITD, internal tandem duplication; TKD, tyrosine kinase domain; NPM1, Nucleophosmin; MTHFR, methylenetetrahydrofolate reductase

${ }^{*}$ FLT-TKD test was started at 2nd trial of external quality assessment of molecular genetic test survey.

\section{2. 분자유전검사}

2013년 분자유전검사 1차 및 2차 신빙도조사에 참여한 기관
의 수는 각각 122 개, 120 개이며 각 항목별 보고결과를 분석한 내용은 Table 4 와 같다. 분자미생물검사의 경우 각 검사실별 
Table 2. Results of cytogenetic survey in 2013

\begin{tabular}{|c|c|c|c|c|c|c|c|}
\hline \multirow{2}{*}{ Specimen } & \multirow{2}{*}{ Karyotype } & \multicolumn{4}{|c|}{ Grading } & \multicolumn{2}{|c|}{ Value } \\
\hline & & M & $S$ & A & $\mathrm{N}$ & Referee & Participants \\
\hline \multirow[t]{3}{*}{$13 \mathrm{CY}-01$} & $46, \mathrm{XX}, \operatorname{del}(4)(\mathrm{q} 32)$ & 1 & 1 & 1 & 1 & $3(75)$ & $26(67)$ \\
\hline & $46, \mathrm{XX}, \operatorname{del}(4)(\mathrm{q} 33)$ & 1 & 1 & 1 & 1 & $1(25)$ & $11(28)$ \\
\hline & $46, \mathrm{XX}, \operatorname{del}(4)(\mathrm{q} 32.2)$ & 1 & 1 & 1 & 1 & 0 & $2(5)$ \\
\hline \multirow[t]{4}{*}{ 13CY-02 } & $46, \mathrm{XX}, \operatorname{del}(2)(\mathrm{q} 11.2 \mathrm{q} 13)$ & 1 & 1 & 1 & 1 & $4(100)$ & $32(82)$ \\
\hline & $46, \mathrm{XX}, \operatorname{del}(2)(\mathrm{q} 13 \mathrm{q} 14.2)$ & 1 & 1 & 1 & 1 & 0 & $3(8)$ \\
\hline & $46, \mathrm{XX}, \operatorname{del}(2)(\mathrm{q} 12.1 \mathrm{q} 13)$ & 1 & 1 & 1 & 1 & 0 & $2(5)$ \\
\hline & $46, \mathrm{XX}$ & 1 & 1 & 3 & 3 & 0 & $2(5)$ \\
\hline \multirow[t]{11}{*}{ 13CY-03 } & $46, \mathrm{XX},+21, \operatorname{der}(21 ; 21)(\mathrm{q} 10 ; \mathrm{q} 10)$ & 1 & 1 & 1 & 1 & $2(50)$ & $19(49)$ \\
\hline & 46,XX,idic(21)(p11.2) & 1 & 1 & 1 & 1 & $1(25)$ & $11(28)$ \\
\hline & $46, \mathrm{XX},+21, \operatorname{dic}(21 ; 21)(\mathrm{p} 11.2 ; \mathrm{p} 11.2)$ & 1 & 1 & 1 & 1 & 0 & $2(3)$ \\
\hline & $46, \mathrm{XX},+21, \operatorname{dic}(21 ; 21)(\mathrm{p} 11.1 ; \mathrm{p} 11.1)$ & 1 & 1 & 1 & 1 & 0 & $1(3)$ \\
\hline & 46,XX,idic(21)(p13) & 1 & 1 & 1 & 1 & 0 & $1(3)$ \\
\hline & $46, \mathrm{XX},+21, \operatorname{rob}(21 ; 21)(\mathrm{q} 10 ; \mathrm{q} 10)$ & 1 & 1 & 1 & 1 & 0 & $1(3)$ \\
\hline & $46, \mathrm{XX}, \mathrm{i}(21)(\mathrm{q} 10)$ & 1 & 1 & 1 & 2 & 0 & $1(3)$ \\
\hline & $46, X X, p s u$ idic(21)(p11.2) & 1 & 1 & 3 & 3 & 0 & $1(3)$ \\
\hline & 46,XX,psu idic(21)(p13) & 1 & 1 & 3 & 3 & $1(25)$ & 0 \\
\hline & $46, \mathrm{X}, \operatorname{del}(\mathrm{X})(\mathrm{p} 22.32),+21, \operatorname{der}(21 ; 21)(\mathrm{q} 10 ; \mathrm{q} 10)$ & 1 & 3 & 3 & 3 & 0 & $1(3)$ \\
\hline & $47, \mathrm{XX},+21$ & 3 & 1 & 3 & 3 & 0 & $1(3)$ \\
\hline \multirow[t]{5}{*}{ 13CY-04 } & $46, \mathrm{XY}, \operatorname{der}(15) \mathrm{t}(15 ; 17)(\mathrm{q} 22 ; \mathrm{q} 21), \operatorname{ider}(17)(\mathrm{q} 10) \mathrm{t}(15 ; 17)[5]$ & 1 & 1 & 1 & 1 & $3(75)$ & $29(74)$ \\
\hline & $46, \mathrm{XY}, \operatorname{der}(15) \mathrm{t}(15 ; 17)(\mathrm{q} 24 ; \mathrm{q} 21), \operatorname{ider}(17)(\mathrm{q} 10) \mathrm{t}(15 ; 17)[5]$ & 1 & 1 & 1 & 1 & $1(25)$ & $5(13)$ \\
\hline & $46, \mathrm{XY}, \operatorname{der}(15) \mathrm{t}(15 ; 17)(\mathrm{q} 22 ; \mathrm{q} 12), \operatorname{ider}(17)(\mathrm{q} 10) \mathrm{t}(15 ; 17)[5]$ & 1 & 1 & 1 & 1 & 0 & $2(2)$ \\
\hline & $46, \mathrm{XY}, \operatorname{der}(15) \mathrm{t}(15 ; 17)(\mathrm{q} 22 ; \mathrm{q} 21), \operatorname{ider}(17)(\mathrm{q} 10) \mathrm{t}(15 ; 17)(\mathrm{q} 22 ; \mathrm{q} 21)[5]$ & 1 & 1 & 1 & 2 & 0 & $2(2)$ \\
\hline & $46, X Y, \operatorname{der}(15) t(15 ; 17)(q 22 ; q 21), \operatorname{ider}(17) t(15 ; 17)[5]$ & 1 & 1 & 3 & 3 & 0 & $1(1)$ \\
\hline \multirow[t]{11}{*}{ 13CY-05 } & $46, \mathrm{XY}, \mathrm{t}(9 ; 11)(\mathrm{p} 22 ; \mathrm{q} 23)[2] / 45$, idem, $\operatorname{der}(10 ; 17)(\mathrm{q} 10 ; \mathrm{q} 10)[3]$ & 1 & 1 & 1 & 1 & $3(75)$ & $26(67)$ \\
\hline & $46, \mathrm{XY}, \mathrm{t}(9 ; 11)(\mathrm{p} 22 ; \mathrm{q} 23)[2] / 45, \mathrm{sl}, \operatorname{der}(10 ; 17)(\mathrm{q} 10 ; \mathrm{q} 10)[3]$ & 1 & 1 & 1 & 1 & $1(25)$ & $3(8)$ \\
\hline & $46, \mathrm{XY}, \mathrm{t}(9 ; 11)(\mathrm{p} 22 ; \mathrm{q} 23)[2] / 45, \mathrm{XY}, \mathrm{t}(9 ; 11)(\mathrm{p} 22 ; 23), \operatorname{der}(10 ; 17)(\mathrm{q} 10 ; \mathrm{q} 10)[3]$ & 1 & 1 & 1 & 1 & 0 & $2(5)$ \\
\hline & $46, \mathrm{XY}, \mathrm{t}(9 ; 11)(\mathrm{p} 22 ; \mathrm{q} 23)[2] / 45, \mathrm{XY}, \mathrm{t}(9 ; 11), \operatorname{der}(10 ; 17)(\mathrm{q} 10 ; \mathrm{q} 10)[3]$ & 1 & 1 & 1 & 1 & 0 & $1(3)$ \\
\hline & $46, \mathrm{XY}, \mathrm{t}(9 ; 11)(\mathrm{p} 22 ; \mathrm{q} 23)[2] / 45, \mathrm{idem}, \operatorname{der}(10) \mathrm{t}(10 ; 17)(\mathrm{p} 13 ; \mathrm{q} 12),-17[3]$ & 1 & 1 & 2 & 2 & 0 & $1(3)$ \\
\hline & $46, \mathrm{XY}, \mathrm{t}(9 ; 11)(\mathrm{p} 22 ; \mathrm{q} 23)[2] / 45, \mathrm{idem},-10, \operatorname{der}(17) \mathrm{t}(10 ; 17)(\mathrm{q} 11.2 ; \mathrm{p} 11.2)[3]$ & 1 & 1 & 2 & 2 & 0 & $1(3)$ \\
\hline & $45, \mathrm{XY}, \mathrm{t}(9 ; 11)(\mathrm{p} 22 ; \mathrm{q} 23), \operatorname{der}(10 ; 17)(\mathrm{q} 10 ; \mathrm{q} 10)[3] / 46, \mathrm{XY}, \mathrm{t}(9 ; 11)(\mathrm{p} 22 ; \mathrm{q} 23)[2]$ & 1 & 1 & 1 & 3 & 0 & $1(3)$ \\
\hline & $46, \mathrm{XY}, \mathrm{t}(9 ; 11)(\mathrm{p} 22 ; \mathrm{q} 23)[2] / 45, \mathrm{XY}, \mathrm{idem}, \operatorname{der}(10 ; 17)(\mathrm{q} 10 ; \mathrm{q} 10)[3]$ & 1 & 1 & 1 & 3 & 0 & $1(3)$ \\
\hline & $46, \mathrm{XY}, \mathrm{t}(9 ; 11)(\mathrm{p} 22 ; \mathrm{q} 23), \operatorname{der}(10 ; 17)(\mathrm{q} 10 ; \mathrm{q} 10)[3] / 46, \mathrm{XY}, \mathrm{t}(9 ; 11)[2]$ & 1 & 1 & 1 & 3 & 0 & $1(3)$ \\
\hline & $46, \mathrm{XY}, \mathrm{t}(9 ; 11)(\mathrm{p} 22 ; \mathrm{q} 23)[5]$ & 1 & 1 & 3 & 3 & 0 & $1(3)$ \\
\hline & $46, \mathrm{XY}, \mathrm{t}(9 ; 11)(\mathrm{p} 22 ; \mathrm{q} 23)[2] / 45, \mathrm{idem}, \operatorname{der}(15 ; 17)(\mathrm{q} 10 ; \mathrm{q} 10)[3]$ & 1 & 1 & 3 & 3 & 0 & $1(3)$ \\
\hline \multirow[t]{6}{*}{ 13CY-06 } & $54, \mathrm{XY},+3,+5,+6,+9,+11, \operatorname{inv}(12)(\mathrm{q} 12 \mathrm{q} 21),+15,+15,+19[5]$ & 1 & 1 & 1 & 1 & $2(50)$ & $11(28)$ \\
\hline & $54, \mathrm{XY},+3,+5,+6,+9,+11, \operatorname{inv}(12)(\mathrm{q} 13.1 \mathrm{q} 21.2),+15,+15,+19[5]$ & 1 & 1 & 1 & 1 & $1(25)$ & $8(21)$ \\
\hline & $54, \mathrm{XY},+3,+5,+6,+9,+11, \operatorname{inv}(12)(\mathrm{q} 12 \mathrm{q} 21.2),+15,+15,+19[5]$ & 1 & 1 & 1 & 1 & $1(25)$ & $5(13)$ \\
\hline & $54, \mathrm{XY},+3,+5,+6,+9,+11, \operatorname{inv}(12)(\mathrm{q} 13 \mathrm{q} 21),+15,+15,+19[5]$ & 1 & 1 & 1 & 1 & 0 & $5(13)$ \\
\hline & $54, \mathrm{XY},+3,+5,+6,+9,+11, \operatorname{inv}(12)(\mathrm{q} 13 \mathrm{q} 15),+15,+15,+19[5$ & 1 & 1 & 1 & 1 & 0 & $3(8)$ \\
\hline & $54, \mathrm{XY},+3,+5,+6,+9,+11, \operatorname{inv}(12)(\mathrm{q} 12 \mathrm{q} 21.3),+15,+15,+19[5]$ & 1 & 1 & 1 & 1 & 0 & $2(5)$ \\
\hline
\end{tabular}


Journal of LABORATORY MEDICINE and QUALITY ASSURANCE

Mi-Ae Jang et al • EQA Report of Diagnostic Genetics (2013)

Table 2. Continued

\begin{tabular}{|c|c|c|c|c|c|c|c|}
\hline \multirow{2}{*}{ Specimen } & \multirow{2}{*}{ Karyotype } & \multicolumn{4}{|c|}{ Grading } & \multicolumn{2}{|c|}{ Value } \\
\hline & & M & $\mathrm{S}$ & A & $\mathrm{N}$ & Referee & Participants \\
\hline & $54, \mathrm{XY},+3,+5,+6,+9,+11, \operatorname{inv}(12)(\mathrm{q} 11 ; \mathrm{q} 21.2),+15,+15,+19[5]$ & 1 & 1 & 1 & 3 & 0 & $1(3)$ \\
\hline & $54, \mathrm{XY},+3,+5,+6,+9,+11, \operatorname{inv}(12)(\mathrm{q} 12 ; \mathrm{q} 15),+15,+15,+19[5]$ & 1 & 1 & 1 & 3 & 0 & $1(3)$ \\
\hline & $54, \mathrm{XY},+3,+5,+6,+9,+11, \operatorname{inv}(12)(\mathrm{q} 12 ; \mathrm{q} 21.1),+15,+15,+19[5]$ & 1 & 1 & 1 & 3 & 0 & $1(3)$ \\
\hline & $54, \mathrm{XY},+3,+5,+6,+9,+11, \operatorname{inv}(12)(\mathrm{q} 13.1 \mathrm{q} 21.2)[5]$ & 1 & 1 & 3 & 3 & 0 & $1(3)$ \\
\hline & $\begin{array}{l}54, \mathrm{XY},+3,+5,+6,+9,+11, \operatorname{inv}(12)(\mathrm{q} 13 \mathrm{q} 21.2),+15,+15,+19[3] / \\
54, \operatorname{idem}, \operatorname{del}(8)(\mathrm{p} 23)[2]\end{array}$ & 1 & 1 & 3 & 3 & 0 & $1(3)$ \\
\hline \multirow[t]{3}{*}{$13 \mathrm{CY}-07$} & $46, \mathrm{XX}, \mathrm{t}(16 ; 21)(\mathrm{q} 24 ; \mathrm{q} 22)[5]$ & 1 & 1 & 1 & 1 & $3(75)$ & $24(62)$ \\
\hline & $46, \mathrm{XX}, \mathrm{t}(16 ; 21)(\mathrm{q} 24 ; \mathrm{q} 22.1)[5]$ & 1 & 1 & 1 & 1 & $1(25)$ & $14(36)$ \\
\hline & $46, \mathrm{XY}, \mathrm{t}(16 ; 21)(\mathrm{q} 24 ; \mathrm{q} 22)[5]$ & 1 & 3 & 1 & 3 & 0 & $1(3)$ \\
\hline \multirow[t]{8}{*}{$13 \mathrm{CY}-08$} & $46, \mathrm{XX}, \mathrm{t}(8 ; 16)(\mathrm{p} 23.1 ; \mathrm{p} 13.1)$ & 1 & 1 & 1 & 1 & $3(75)$ & $8(72)$ \\
\hline & $46, \mathrm{XX}, \mathrm{t}(8 ; 16)(\mathrm{p} 23.3 ; \mathrm{p} 13.3)$ & 1 & 1 & 1 & 1 & 0 & $4(10)$ \\
\hline & $46, \mathrm{XX}, \mathrm{t}(8 ; 16)(\mathrm{p} 23.2 ; \mathrm{p} 13.2)$ & 1 & 1 & 1 & 1 & $1(25)$ & $2(5)$ \\
\hline & $46, \mathrm{XX}, \mathrm{t}(8 ; 16)(\mathrm{p} 23.1 ; \mathrm{p} 12)$ & 1 & 1 & 1 & 1 & 0 & $1(3)$ \\
\hline & $46, \mathrm{XX}, \mathrm{t}(8 ; 16)(\mathrm{p} 23.1 ; \mathrm{p} 13.2)$ & 1 & 1 & 1 & 1 & 0 & $1(3)$ \\
\hline & 46,XX,del(16)(p13.2) & 1 & 1 & 3 & 3 & 0 & $1(3)$ \\
\hline & $46, \mathrm{XX}, \operatorname{del}(16)(\mathrm{p} 13.3)$ & 1 & 1 & 3 & 3 & 0 & $1(3)$ \\
\hline & 46,XX,del(16)(p13) & 1 & 1 & 3 & 3 & 0 & $1(3)$ \\
\hline \multirow[t]{5}{*}{ 13CY-09 } & 46,XX,del(2)(q37.1) & 1 & 1 & 1 & 1 & $2(50)$ & $17(44)$ \\
\hline & 46,XX,del(2)(q36) & 1 & 1 & 1 & 1 & $2(50)$ & $15(38)$ \\
\hline & 46,XX,del(2)(q37) & 1 & 1 & 1 & 2 & 0 & $3(8)$ \\
\hline & 46,XX,del(2)(q36q37.2) & 1 & 1 & 3 & 3 & 0 & $3(8)$ \\
\hline & $46, \mathrm{XX}, \mathrm{t}(2 ; 6)(\mathrm{q} 37.1 ; \mathrm{p} 23)$ & 1 & 1 & 3 & 3 & 0 & $1(3)$ \\
\hline \multirow[t]{7}{*}{$13 \mathrm{CY}-10$} & $46, \mathrm{XX}$ & 1 & 1 & 1 & 1 & $4(100)$ & $26(67)$ \\
\hline & 46,XX,1qh+,16qh+ & 1 & 1 & 1 & 2 & 0 & $6(15)$ \\
\hline & $46, \mathrm{XX}, 16 \mathrm{qh}+$ & 1 & 1 & 1 & 2 & 0 & $3(8)$ \\
\hline & $46, \mathrm{XX}, 16 \mathrm{gh}+$ & 1 & 1 & 1 & 3 & 0 & $1(3)$ \\
\hline & $46, \mathrm{XX},+16 \mathrm{qh}$ & 1 & 1 & 1 & 3 & 0 & $1(3)$ \\
\hline & 46,XX,1gh+,16gh+ & 1 & 1 & 1 & 3 & 0 & $1(3)$ \\
\hline & $\operatorname{mos} 46, \mathrm{XX}, 1 \mathrm{qh}+, \operatorname{del}(1)(\mathrm{q} 21 \mathrm{q} 21), 16 \mathrm{qh}+[10] / 46, \mathrm{XX}, 1 \mathrm{qh}+, 16 \mathrm{qh}+[20]$ & 1 & 1 & 3 & 3 & 0 & $1(3)$ \\
\hline
\end{tabular}

Values are presented as number (\%).

Abbreviations: M, modal chromosome number; S, sex chromosome designation; A, recognition of abnormalities; $\mathrm{N}$, karyotype nomenclature; $\square$, not graded; 1, good performance; [2] acceptable performance; 3] unacceptable performance.

로 다양한 검사법과 시약이 사용되고 있었으며 Tables 5-8과 같다.

\section{고찰}

염색체검사 정도관리 $13 \mathrm{CY}-01$ 은 초음파 이상소견을 보 인 21주된 산모의 양수에서 관찰된 46,XX,del(4)(q32) 증례 로서 참여한 43 개 기관 모두 해당 염색체의 이상을 정확하게
기술하였다. $13 \mathrm{CY}-02$ 는 저신장과 지능저하를 보인 4세 환 아의 말초혈액에서 관찰된 46,XX,del(2)(q11.2q13) 증례였 다. 전체 2 기관(5.1\%)에서 target value를 발견하지 못하고 정상 karyotype $(46, X X)$ 으로 표기하여 unacceptable로 평 가하였다. $13 \mathrm{CY}-03$ 은 심장초음파검사상 심장기형이 발견되 어 내원한 생후 4 개월 환아의 말초혈액 검체에서 발견된 염색 체 이상으로 핵형의 target value는 46,XX, +21 ,der(21;21) (q10;q10) 또는 46,XX,idic(21)(p11.2)인 증례였다. 전체 
Journal of LABORATORY MEDICINE and QUALITY ASSURANCE

Mi-Ae Jang et al • EQA Report of Diagnostic Genetics (2013)

Table 3. Distribution of the methods and probe types used for FISH survey and results of participants during 2013

\begin{tabular}{|c|c|c|c|c|c|}
\hline Specimen & Intended responses & Manufacturer & Probe type & N laboratories & Acceptable response, $\mathbf{n} / \mathbf{N}^{\star}(\%)$ \\
\hline \multirow[t]{2}{*}{ 13CYF-01 } & Consistent with Trisomy 21 & Vysis & Single color/others & $11(4)$ & $18 / 18(100.0)$ \\
\hline & & CytoCell & Single color & 2 & \\
\hline \multirow[t]{2}{*}{ 13CYF-02 } & Abnormal with $B C R / A B L$ fusion & Vysis & Dual fusion & 23 & $26 / 26(100.0)$ \\
\hline & & CytoCell & Dual fusion & 2 & \\
\hline \multirow[t]{3}{*}{ 13CYF-03 } & Abnormal with loss of EGR1 (5q31) & Vysis & Dual color/others & $13(2)$ & $18 / 18(100.0)$ \\
\hline & & CytoCell & Dual color & 2 & \\
\hline & & Mirax & Dual color & 1 & \\
\hline 13CYF-06 & Consistent with Trisomy 21 & Vysis & Single color/others & $13(2)$ & $18 / 18(100.0)$ \\
\hline \multirow{2}{*}{ 13CYF-07 } & & CytoCell & Dual fusion & 2 & \\
\hline & & Mirax & Dual fusion & 1 & \\
\hline \multirow[t]{3}{*}{ 13CYF-08 } & Abnormal with loss of $C B F B$ & Vysis & Break-apart & 17 & $18 / 19(95)$ \\
\hline & & CytoCell & Dual fusion & 1 & \\
\hline & & Mirax & Dual fusion & 1 & \\
\hline \multirow[t]{2}{*}{ 13CYF-09 } & Abnormal with $A M L 1 / E T O$ fusion & Vysis & Dual fusion & 22 & $23 / 23(100.0)$ \\
\hline & & CytoCell & Dual fusion & 1 & \\
\hline
\end{tabular}

The following FISH method was used: Vysis (Illinois, USA), CytoCell (Cambridge, UK), Mirax (Altlussheim, Germany), and Kreatech (Amsterdam, Netherland).

Abbreviations: FISH, fluorescent in situ hybridization; EGR1, early growth response 1; $C B F B$, core-binding factor, beta subunit. ${ }^{*} \mathrm{n} / \mathrm{N}$ indicates the acceptable no./total no. of participants.

참여기관 중 target value를 발견하지 못하거나(1개 기관, $2.3 \%)$, target value에 없는 $\operatorname{del}(\mathrm{X})(\mathrm{p} 22.32)$ 를 추가로 표기 (1개 기관, $2.3 \%$ ) 또는 pseudo-isodicentric chromosome으 로 잘못 표기한 2개 기관(4.5\%)에 대해서 unacceptable로 평 가하였다. 13CY-04은 멍과 육안적 혈뇨소견을 보인 27세 환 자의 골수 검체에서 관찰된 염색체 이상으로 46,XY, $\operatorname{der}(15)$ $\mathrm{t}(15 ; 17)(\mathrm{q} 22 ; \mathrm{q} 21), \mathrm{ider}(17)(\mathrm{q} 10) \mathrm{t}(15 ; 17)$ 증례였다. 전체 기관 중 target value의 ider(17)(q10)t(15;17)을 ider(17) $\mathrm{t}(15 ; 17)$ 로 잘못 표기한 1 개 기관(2.3\%)을 unacceptable 로 평가하였다. $13 \mathrm{CY}-05$ 는 지혈되지 않는 잇몸 출혈을 보 인 43세 남자의 골수 검체에서 관찰된 염색체 이상소견 으로 핵형의 target value는 46,XY,t(9;11)(p22;q23)[2] 〔KHJ4]/45,sl,der(10;17) (q10;q10) [3] 또는 46,XY,t(9;11) (p22; q23) [2]/45,idem, der (10;17) (q10; q10) [3]였다. Stemline 이외 여러 개의 관련된 subclone을 가지고 있는 경 우 핵형을 표기할 때에는 stemline을 첫 번째로 표기하고 뒤
에 연관된 subclone을 기술해야 하며, 이때 stemline에 해당 하는 동일한 염색체 이상 표기는 생략하고, 추가적인 이상소 견만 기술하는 것이 원칙이다[5]. 그러나 전체 기관 중 3 개 기 관(7.0\%)에서는 subclone을 먼저 표기하거나, 정상 성염색체 의 반복 표기 또는 동일한 재배열에 의해 생성된 유도 염색체 의 절단점을 반복 표기하는 등의 오류로 unacceptable로 평가 되었다. 그 외에도 subclone $\operatorname{der}(10 ; 17)(\mathrm{q} 10 ; \mathrm{q} 10)$ 의 염색체 이상소견을 발견하지 못하거나(1개 기관, $2.3 \%), 15$ 번과 17 번 염색체의 whole arm translocation으로 잘못 표기한 경우(1 개 기관, $2.3 \%$ ) 또한 unacceptable로 평가하였다. $13 \mathrm{CY}-06$ 는 허리 통증으로 내원한 61 세 다발성 골수종 환자의 골수에서 관찰된 염색체 이상으로 $54, \mathrm{XY},+3,+5,+6,+9,+11$,inv(12) (q12q21), $+15,+15,+19[5]$ 증례였다. 전체 기관 중 3 개 기 관(7.0\%)은, 단독 염색체의 재배열에서는 세미콜론(;)을 표 기하지 않으나 세미콜론을 표기하여 unacceptable로 평가하 였다. Target value인 15번, 19번 염색체의 획득을 발견하지 
Journal of LABORATORY MEDICINE and QUALITY ASSURANCE

Mi-Ae Jang et al • EQA Report of Diagnostic Genetics (2013)

Table 4. Results of molecular genetic test survey during 2013

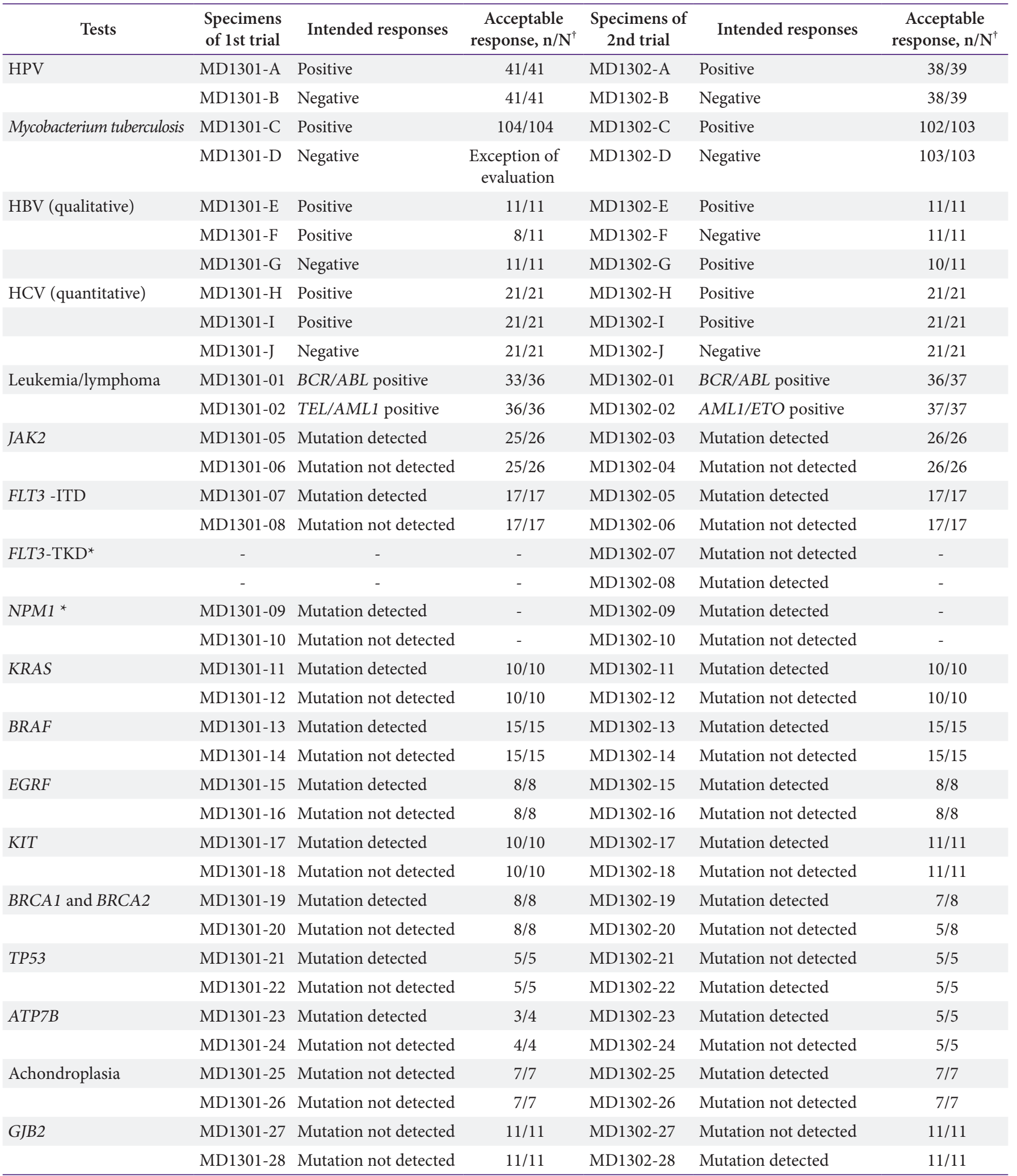

(Continued to the next page) 
Journal of LABORATORY MEDICINE and QUALITY ASSURANCE

Mi-Ae Jang et al • EQA Report of Diagnostic Genetics (2013)

Table 4. Continued

\begin{tabular}{|c|c|c|c|c|c|c|}
\hline Tests & $\begin{array}{l}\text { Specimens } \\
\text { of } 1 \text { st trial }\end{array}$ & Intended responses & $\begin{array}{c}\text { Acceptable } \\
\text { response, } n / N^{\dagger}\end{array}$ & $\begin{array}{l}\text { Specimens of } \\
\text { 2nd trial }\end{array}$ & Intended responses & $\begin{array}{c}\text { Acceptable } \\
\text { response, } n / N^{\dagger}\end{array}$ \\
\hline \multirow[t]{2}{*}{ TGFBI } & MD1301-29 & Mutation detected & $12 / 12$ & MD1302-29 & Mutation detected & $12 / 12$ \\
\hline & MD1301-30 & Mutation not detected & $12 / 12$ & MD1302-30 & Mutation not detected & $12 / 12$ \\
\hline \multirow[t]{2}{*}{ HD } & MD1301-31 & HD positive & $4 / 4$ & MD1302-31 & HD positive & $4 / 4$ \\
\hline & MD1301-32 & HD positive & $4 / 4$ & MD1302-32 & HD negative & $4 / 4$ \\
\hline \multirow[t]{2}{*}{ SCA } & MD1301-33 & SCA positive & $4 / 4$ & MD1302-33 & SCA positive & $4 / 4$ \\
\hline & MD1301-34 & SCA negative & $4 / 4$ & MD1302-34 & SCA negative & $4 / 4$ \\
\hline \multirow[t]{2}{*}{ SBMA } & MD1301-35 & SBMA positive & $3 / 3$ & MD1302-35 & SBMA positive & $3 / 3$ \\
\hline & MD1301-36 & SBMA negative & $3 / 3$ & MD1302-36 & SBMA negative & $3 / 3$ \\
\hline \multirow[t]{2}{*}{ MELAS } & MD1301-37 & Mutation detected & $4 / 5$ & MD1302-37 & Mutation detected & $4 / 5$ \\
\hline & MD1301-38 & Mutation not detected & $5 / 5$ & MD1302-38 & Mutation not detected & $5 / 5$ \\
\hline \multirow[t]{2}{*}{ MERRF } & MD1301-39 & Mutation detected & $4 / 4$ & MD1302-39 & Mutation not detected & $4 / 4$ \\
\hline & MD1301-40 & Mutation not detected & $4 / 4$ & MD1302-40 & Mutation detected & $4 / 4$ \\
\hline \multirow[t]{2}{*}{ PW/AS } & MD1301-41 & PW positive & $4 / 4$ & MD1302-41 & PW positive & $4 / 4$ \\
\hline & MD1301-42 & PW/AS negative & $4 / 4$ & MD1302-42 & AS positive & $4 / 4$ \\
\hline \multirow[t]{2}{*}{ DMD } & MD1301-43 & DMD positive & $5 / 5$ & MD1302-43 & DMD positive & $6 / 6$ \\
\hline & MD1301-44 & DMD positive & $5 / 5$ & MD1302-44 & DMD negative & $6 / 6$ \\
\hline \multirow[t]{2}{*}{ SMA } & MD1301-45 & SMA positive & $5 / 5$ & MD1302-45 & SMA negative & $5 / 5$ \\
\hline & MD1301-46 & SMA positive/negative & $4 / 5$ & MD1302-46 & SMA positive & $5 / 5$ \\
\hline \multirow[t]{2}{*}{ APOE genotype } & MD1301-47 & $A P O E \varepsilon 3 / \varepsilon 4$ genotype & $33 / 33$ & MD1302-47 & $A P O E \varepsilon 3 / \varepsilon 4$ genotype & $35 / 35$ \\
\hline & MD1301-48 & $A P O E \varepsilon 2 / \varepsilon 3$ genotype & $33 / 33$ & MD1302-48 & $A P O E \varepsilon 3 / \varepsilon 3$ genotype & $35 / 35$ \\
\hline \multirow[t]{2}{*}{ MTHFR genotype } & MD1301-49 & $677 \mathrm{C} / \mathrm{T}$ heterozygote & $9 / 15$ & MD1302-49 & $677 \mathrm{C} / \mathrm{T}$ heterozygote & $12 / 14$ \\
\hline & MD1301-50 & wild type & $15 / 15$ & MD1302-50 & 677C/T heterozygote & $12 / 14$ \\
\hline \multirow[t]{2}{*}{ ABO genotype } & MD1301-51 & cis- $\mathrm{AB} / \mathrm{O}$ genotype & $9 / 9$ & MD1302-51 & A/B genotype & $9 / 9$ \\
\hline & MD1301-52 & A/B genotype & $9 / 9$ & MD1302-52 & cis- $A B / O$ genotype & $9 / 9$ \\
\hline \multirow[t]{2}{*}{$F M R 1$} & MD1301-53 & Mutation detected & $7 / 8$ & MD1302-53 & Mutation detected & $7 / 7$ \\
\hline & MD1301-54 & Mutation not detected & $8 / 8$ & MD1302-54 & Mutation detected & $7 / 7$ \\
\hline \multirow[t]{4}{*}{ DNA sequencing } & SEC1301-01 & NF1 mutation & $13 / 14$ & SEC1302-01 & $D M D$ mutation & $15 / 16$ \\
\hline & SEC1301-02 & TSC1 mutation & $14 / 14$ & SEC1302-02 & VHL mutation & $16 / 16$ \\
\hline & SEC1301-03 & KCNQ1 mutation & $14 / 14$ & SEC1302-03 & $A B C D 1$ mutation & $12 / 16$ \\
\hline & SEC1301-04 & MLH1 mutation & $11 / 14$ & SEC1302-03 & NOTCH3 mutation & $16 / 16$ \\
\hline
\end{tabular}

Abbreviations: HPV, human papilloma virus; HBV, hepatitis B virus; HCV, hepatitis C virus; NTM, nontuberculous mycobacteria; HD, Huntington disease; SCA, spinocerebellar ataxia; SBMA, spinal and bulbar mulscular atrophy; MELAS, mitochondrial encephalomyopathy, lactic acidosis, and stroke-like episodes; MERRF, myoclonic epilepsy with ragged red fibers; PW/AS, Prader-Willi/Angelman syndrome; DMD, Duchenne muscular dystrophy; SMA, spinal muscular atrophy; FLT3, fms-related tyrosine kinase 3; ITD, internal tandem duplication; TKD, tyrosine kinase domain; NPM1, Nucleophosmin; MTHFR, methylenetetrahydrofolate reductase.

${ }^{*}$ Educational challenge, FLT-TKD test was started at 2 nd trial of external quality assessment of molecular genetic test survey; ${ }^{\dagger} \mathrm{n} / \mathrm{N}$ indicates the acceptable no./total no. of participants.

못했거나(1개 기관, $2.3 \%$ ), target value에 없는 8 번 염색체 의 결실을 보고(1개 기관, $2.3 \%$ )한 경우 또한 unacceptable로 평가하였다. $13 \mathrm{CY}-07$ 은 급성 백혈병이 의심되어 내원한 50 세 환자의 골수에서 관찰된 염색체 이상으로 $46, \mathrm{XX}, \mathrm{t}(16 ; 21)$ (q24;q22)[5] 증례였다. 전체 기관 중 1개 기관(2.3\%)에서 성 염색체를 XY로 잘못 표기하여 unacceptable로 평가하였다. $13 \mathrm{CY}-08$ 은 운동실조와 발달장애를 보이며 영상의학적 검사 상 소뇌 무형성증이 의심되는 2 세 환아의 말초혈액에서 관찰 
Mi-Ae Jang et al • EQA Report of Diagnostic Genetics (2013)

Table 5. HPV detection methods in molecular genetic test survey in 2013

\begin{tabular}{llcc}
\hline \multicolumn{1}{c}{ Manufacturer } & \multicolumn{1}{c}{ Kit } & $\begin{array}{c}\text { No. of participants } \\
\text { (1st trial) }\end{array}$ & $\begin{array}{c}\text { No. of participants } \\
\text { (2nd trial) }\end{array}$ \\
\hline BioCore (Seoul, Korea) & HPV Screening PCR Kit & 1 & 2 \\
BioCore (Seoul, Korea) & HPV 16/18 PCR Kit & 2 & 1 \\
BioMedLab (Seoul, Korea) & HPV DNA Chip & 16 & 13 \\
Goodgene (Seoul, Korea) & HPV Genotyping Chip & 0 & 2 \\
Qiagen (Hilden, Germany) & HC2 HPV DNA test & 22 & 21 \\
Seegene (Seoul, Korea) & Seeplex HPV 4A ACE Screening & 2 & 2 \\
Others & Others & 4 & 4 \\
Total & & 47 & 45 \\
\hline
\end{tabular}

Abbreviation: HPV, human papilloma virus.

Table 6. M. tuberculosis detection methods in molecular genetic test survey in 2013

\begin{tabular}{llcc}
\hline \multicolumn{1}{c}{ Manufacturer } & \multicolumn{1}{c}{ Kit } & $\begin{array}{c}\text { No. of participants } \\
\text { (1st trial) }\end{array}$ & $\begin{array}{c}\text { No. of participants } \\
\text { (2nd trial) }\end{array}$ \\
\hline Roche (Basel, Swiss) & COBAS AMPLICOR MTB Test & 1 & 0 \\
Roche (Basel, Swiss) & COBAS Taqman MTB Test & 24 & 23 \\
Biosewoom (Seoul, Korea) & MTB PCR Kit & 2 & 2 \\
Biosewoom (Seoul, Korea) & NTM \& MTB PCR Kit & 9 & 9 \\
Seegene (Seoul, Korea) & Seeplex TB Detection 2 & 1 & 0 \\
Seegene (Seoul, Korea) & Seeplex MTB nested ACE detection & 4 & 4 \\
Seegene (Seoul, Korea) & Anyplex MTB/NTM Real-time Detection & 5 & 6 \\
BioCore (Seoul, Korea) & TB/NTM Real-time PCR & 1 & 2 \\
Bioneer (Daejeon, Korea) & MTB Real-time PCR & 14 & 12 \\
LG Lifescience (Seoul, Korea) & AdvanSure TB/NTM real-time PCR & 38 & 1 \\
YD Diagnostics (Gyeonggi-do, Korea) & YD Diagnostics Real TB-Tag & 1 & 1 \\
Panagene (Daejeon, Korea) & TB/NTM Detection Kit & 1 & 7 \\
Others & Others & 7 & 107 \\
Total & & 108 & \\
\hline Abbrever & & \\
\hline
\end{tabular}

Abbreviations: MTB, Mycobacterium tuberculosis; NTM, nontuberculous mycobacteria.

된 염색체 이상으로 46,XX,t(8;16)(p23.1;p13.1) 증례였다. 전체 기관 중에서 3 개 기관(7.0\%)은 target value인 t(8;16) 을 발견하지 못하여 unacceptable로 평가하였다. 13CY-09 은 안면기형과 발달장애가 있는 10 개월 환아의 말초혈액에 서 관찰된 염색체 이상으로 2 번 염색체 장완의 $2 \mathrm{q} 36$ 을 절단점 으로 하는 말단부 결실(terminal deletion)을 보인 증례였다. 전체 기관 중 target value인 2번 염색체 장완의 말단부 결실 을 간질성 결실(interstitial deletion)로 잘못 해석한 3 개 기관 (7.0\%)과 말단부 결실을 발견하지 못한 1 개 기관 $(2.3 \%)$ 에 대 해서 unacceptable로 평가하였다. 13CY-10은 양수에서 염색 에 이상이 확인된 태아의 부모로부터 채취한 말초혈액 검체로
정상 핵형 증례였다. 참가기관 중 heteromorphism의 표기와 관련하여 ' 'q'를 ' $\mathrm{g}$ '로 잘못 표기한 2 개 기관(4.6\%)과 '+/-' sign 은 symbol h 뒤가 아닌 염색체 앞에 표기한 1 개 기관(2.3\%)은 unacceptable로 평가하였다.

$\mathrm{FISH}$ 검사항목은 1차에 총 3예로서 각각 trisomy 21이 있 는 검체, $B C R / A B L 1$ 재배열이 있는 검체, $E G R 1$ 이상이 있 는 검체였으며, 모든 참여기관에서 항목별 해당하는 이상소 견을 올바르게 판독하였다. 2차 FISH검사항목은 총 4예로 각 항목별로는 trisomy 21이 있는 검체, DiGeorge syndrome과 관련한 22q11.2 region의 결실이 있는 검체, $C B F B$ 이상 및 $A M L 1 / E T O$ 재배열이 있는 검체였으며 CBFB loss를 'within 
Mi-Ae Jang et al • EQA Report of Diagnostic Genetics (2013)

Table 7. HBV detection methods in molecular genetic test survey in 2013

\begin{tabular}{|c|c|c|c|c|}
\hline Test & Manufacturer & Method & $\begin{array}{c}\text { No. of participants } \\
\text { (1st trial) }\end{array}$ & $\begin{array}{l}\text { No. of participants } \\
\text { (2nd trial) }\end{array}$ \\
\hline \multirow[t]{5}{*}{ Qualitative } & BioCore (Seoul, Korea) & HBV PCR Kit & 2 & 2 \\
\hline & DiaProbe (Seoul, Korea) & Opti One step HBV test & 1 & 1 \\
\hline & Genotech (Daejeon, Korea) & HBV PrimerMix Kit & 1 & 1 \\
\hline & Seegene (Seoul, Korea) & HepaTrio Real-time PCR Test & 2 & 2 \\
\hline & Others & Others & 5 & 5 \\
\hline Total & & & 11 & 11 \\
\hline \multirow[t]{8}{*}{ Quantitative } & Roche (Basel, Swiss) & COBAS TaqMan & 71 & 71 \\
\hline & Bayer (Newyork, USA) & VERSANT HBV DNA Assay & 2 & 3 \\
\hline & Artus (Qiagen, Hilden, Germany) & HBV Real-time PCR Kit & 2 & 2 \\
\hline & Abbott (Illinois, USA) & HBV Real-time PCR Kit & 19 & 20 \\
\hline & Biosewoom (Seoul, Korea) & HBV Real-time PCR Kit & 1 & 1 \\
\hline & LG Lifescience (Seoul, Korea) & AdvanSure HBV Real-time PCR Kit & 8 & 8 \\
\hline & Bioneer (Daejeon, Korea) & HBV Quantiative Kit & 7 & 7 \\
\hline & Others & Others & 0 & 1 \\
\hline Total & & & 110 & 113 \\
\hline
\end{tabular}

Abbreviation: HBV, hepatitis B virus.

Table 8. HCV detection methods in molecular genetic test survey in 2013

\begin{tabular}{|c|c|c|c|c|}
\hline Specimen & Manufacturer & Method & $\begin{array}{l}\text { No. of participants } \\
\text { (1st trial) }\end{array}$ & $\begin{array}{l}\text { No. of participants } \\
\text { (2nd trial) }\end{array}$ \\
\hline \multirow[t]{6}{*}{ Qualitative } & Roche (Basel, Swiss) & AMPLICOR HCV Test & 6 & 6 \\
\hline & Abbott (Illinois, USA) & HCV Real-time PCR Kit & 3 & 4 \\
\hline & Seegene (Seoul, Korea) & HepaTrio Real-Time PCR Test & 3 & 3 \\
\hline & BioCore (Seoul, Korea) & HCV PCR Kit & 1 & 1 \\
\hline & Biosewoom (Seoul, Korea) & HCV Real-time PCR Kit & 0 & 1 \\
\hline & Others & Others & 8 & 6 \\
\hline Total & & & 21 & 21 \\
\hline \multirow[t]{5}{*}{ Quantitative } & Roche (Basel, Swiss) & AMPLICO HCV MONITOR Test & 1 & 1 \\
\hline & Roche (Basel, Swiss) & COBAS TaqMan & 44 & 46 \\
\hline & Abbott (Illinois, USA) & HCV Real-time PCR Kit & 10 & 11 \\
\hline & Biosewoom (Seoul, Korea) & HCV Real-time PCR Kit & 1 & 1 \\
\hline & Artus (Qiagen, Hilden, Germany) & HCV Real-time PCR Kit & 1 & 1 \\
\hline Total & & & 57 & 60 \\
\hline
\end{tabular}

Abbreviation: HCV, hepatitis C virus.

normal limits for $C B F B$ 로 판독한 1 개 기관을 제외하고 모 든 참여기관에서 항목별 해당하는 이상소견을 올바르게 판독 하였다. 하지만 각 기관별로 nomenclature 표기는 다양하여 ISCN 2009 또는 2013 기준에 맞지 않게 보고하는 경우가 일 부 기관에서 관찰되어 향후 지속적인 교육 및 정도관리가 필요
함을 확인할 수 있었다.

2013년 1차 및 2차 분자유전검사 신빙도조사에 참여한 기 관은 각각 122 개, 120 개 기관이었다. 분자미생물검사는 HPV, 결핵균, $\mathrm{HBV}, \mathrm{HCV}$ 4종류에 대해 시행하였는데 1차에서는 각각 41 개, 104 개, 109 개, 57 개 기관이, 2 차 신빙도조사에서 


\section{Journal of LABORATORY MEDICINE and QUALITY ASSURANCE}

Mi-Ae Jang et al EQA Report of Diagnostic Genetics (2013)

는 각각 39 개, 103 개, 114 개, 63 개 기관이 참가하였다. 분자유 전검사에는 1 차에서 31 개 종목, 2 차에서 32 개 종목을 시행하 였다. 검사항목은 1 차에서는 NPM1 분자유전검사와 FLT3$\mathrm{TKD}$ 분자유전검사를 신규로 추가하여, 혈액종양 6종목, 고형 종양 3 종목, 선천성 유전질환 15 종목, 유전형 검사 3 종목, 염 기서열분석 4 문항으로 구성하였다. 분자미생물검사의 결핵균 검사에서 키트 사용기관의 비율은 1999 년 $66 \%$ 였으나, 해마 다 점차 증가하여 2013년은 $94 \%$ 로 증가하였다. HPV검사법 은 Hybrid Capture 2 (Qiagen, Hilden, Germany)가 가장 많이 사용되었다(Table 5). HBV, HCV 정량검사법은 Roche (Basel, Swiss)사의 Kit가 가장 많이 사용되었고, 그 다음으로 Abbott (Abbott Park, IL, USA)사의 Kit가 많이 사용된 것으 로 분석되었다(Tables 7,8 ).

2013년도 분자미생물, 분자유전검사 정도관리는 전체적 으로 우수한 결과를 보였다. 그러나 SMA와 methylenetetrahydrofolate reductase (MTHFR) genotyping에서 일부 기관이 결과해석에서 예상결과와 불일치한 결과를 보고하였 으며, DNA 염기서열분석항목의 경우 염기변이의 명명과 해석 에서 예상결과와 다른 결과를 보고한 기관이 있었다. 유전자변 이 명명과 보고의 경우, Human Genome Variation Society 및 American College of Medical Genetics 관련 지침을 준수 하도록 권장되고 있으며 [6,7], 따라서 각 분자유전검사에서 돌 연변이를 검출하는 것뿐만 아니라 염기변이의 명명과 해석에 있어 주의가 필요할 것으로 판단된다. $\mathrm{HBV}, \mathrm{HCV}$ 검사의 경 우, 정성 및 정량검사가 모두 포함되므로, 3 개 검체로 문항을 구성하였다. HBV검사에서 low positive 검체에 대하여 1차에 서 3 개 기관이 2 차에서 1 개 기관이 예상결과와 불일치한 결과 를 보고하여 검사법의 민감도에 대한 재평가가 필요할 것으로 판단되었다.

결론적으로 2013년 시행한 진단유전학분과 신빙도조사결과 는 전체적으로 우수한 결과를 보였다. 진단유전학은 임상적인 중요성과 검사항목이 크게 증가하는 검사로 각 검사실에서는 지속적인 신빙도조사사업 참여를 통하여 검사의 질적인 측면 을 더욱 향상시켜나가야 할 것으로 생각된다.

\section{진단유전학분과 위원(2013)}

김선희(위원장, 성균관대학교 의과대학), 김은지(간사, 삼
성서울병원), 김종원(성균관대학교 의과대학), 조현찬(한림대 학교 의과대학), 박성섭(서울대학교 의과대학), 이우인(경희 대학교 의과대학), 서을주(울산대학교 의과대학), 이유경(순 천향대학교 의과대학), 김재석(한림대학교 의과대학), 기승정 (전남대학교 의과대학), 기창석(성균관대학교 의과대학), 공 선영(국립암센터), 김지명(충남대학교 의과대학), 한성희(서 울의과학연구소), 탁은영(삼성서울병원), 이지영(서울아산병 원), 조성임(서울대학교병원)

\section{REFERENCES}

1. Kim SH, Ki CS, Jeon BR, Lee ST, Yoo EH, Kim JW, et al. Annual report on external quality assessment in diagnostic genetics in Korea (2008). J Lab Med Qual Assur 2009;31:161-81.

2. Kim SH, Ki CS, Kim JH, Oh SH, Kim JW, Park SS, et al. Annual report on external quality assessment in diagnostic genetics in Korea (2007). J Lab Med Qual Assur 2008;30:167-87.

3. Kim SH, Ki CS, Kim S, Kwon MJ, Kim JW, Park SS, et al. Annual report on external quality assessment in diagnostic genetics in Korea (2009). J Lab Med Qual Assur 2010;32:147-70.

4. Kim SH, Kim JW, Ki CS, Kim IS, Nam MH, Cho HJ, et al. Annual report on external quality assessment in diagnostic genetics in Korea (2005). J Lab Med Qual Assur 2006;28:153-67.

5. Shaffer LG, McGowan-Jordan J, Schmid M; International Standing Committee on Human Cytogenetic Nomenclature. ISCN 2013: an international system for human cytogenetic nomenclature (2013). Basel: S. Karger, 2013.

6. Richards CS, Bale S, Bellissimo DB, Das S, Grody WW, Hegde MR, et al. ACMG recommendations for standards for interpretation and reporting of sequence variations: revisions 2007. Genet Med 2008;10:294-300.

7. Zhang VW, Wang J. Determination of the clinical significance of an unclassified variant. Methods Mol Biol 2012; 837:337-48. 
진단유전학분과 신빙도조사 결과보고(2013) 장미애 ${ }^{1}$ - 신상용 ${ }^{1}$ 박승만 ${ }^{2,3}$ - 성문우 ${ }^{2}$ - 박성섭 ${ }^{2}$ - 김선희 $\left.\right|^{1}$ - 대한임상검사정도 관리협회 진단유전학분과위원회

${ }^{1}$ 성균관대학교 의과대학 삼성서울병원 진단검사의학과, ${ }^{2}$ 서울대학교 의과대학 서울대학교병원 진단검사의 학과, ${ }^{3}$ 녹십자의료재단

진단유전분과에서의 외부정도관리는 임상적 중요성과 검사항목이 점차 증가함에 따라 더욱 중요 해지고 있는 항목이다. 2013년 세포유전검사와 분자유전검사에 대한 각 2회의 신빙도조사가 실 시되었다. 세포유전학 분야는 43개 기관이, 형광제자리부합법(fluorescent in situ hybridization, $\mathrm{FISH}$ ) 분야는 30 개 기관이 참여하였으며, 분자유전검사 분야는 122 개 기관이 참여하였다. 세포유

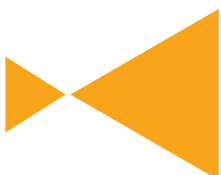

Journal of LABORATORY MEDICINE and

QUALITY ASSURANCE 전학 분야에서 대부분의 기관이 우수한 결과를 보였으나 43 개 기관 중 1 개 기관은 염색체 명명법과 복잡 염색체 이상을 확인하지 못하여 불합격 판정을 받았고, FISH 분야는 1개 기관을 제외하고 모 두 합격 판정을 받았다. 분자유전검사 분야는 human papilloma virus, M. tuberculosis, B형 간 염 바이러스, C형 간염 바이러스, 백혈병/림프종 분자진단검사, JAK2, FLT3-ITD, FLT3-TKD, KRAS, EGFR, BRAF, KIT, BRCA1/2, TP53, ATP7B, FGFR3, HD, SCA, SBMA, MELAS, MERRF, PW/AS, DMD, SMA, FMR1, GJB2, KIT, TGFBI 분자진단검사, ABO, APOE 및 methylenetetrahydrofolate reductase 유전자형검사, DNA 염기서열분석 평가를 시행하였고, 대 부분의 기관에서 합격 판정을 받았다. 2013년 시행한 진단유전학분과 신빙도조사는 각 기관에 대한 지속적인 교육효과와 더불어 검사의 양과 질적인 측면에 있어서 더욱 향상된 결과를 보였다.

(J Lab Med Qual Assur 2014;36:71-83) 